University of Nebraska - Lincoln

DigitalCommons@University of Nebraska - Lincoln

2012

\title{
Estimating the Abundance of Long-billed Curlews in Nebraska
}

Cory J. Gregory

lowa State University

Stephen J. Dinsmore

lowa State University, cootjr@iastate.edu

Larkin A. Powell

University of Nebraska-Lincoln, Ipowell3@unl.edu

Joel G. Jorgensen

Nebraska Game and Parks Commission, joel.jorgensen@nebraska.gov

Follow this and additional works at: https://digitalcommons.unl.edu/natrespapers

Part of the Natural Resources and Conservation Commons, Natural Resources Management and Policy Commons, and the Other Environmental Sciences Commons

Gregory, Cory J.; Dinsmore, Stephen J.; Powell, Larkin A.; and Jorgensen, Joel G., "Estimating the Abundance of Long-billed Curlews in Nebraska" (2012). Papers in Natural Resources. 363.

https://digitalcommons.unl.edu/natrespapers/363

This Article is brought to you for free and open access by the Natural Resources, School of at DigitalCommons@University of Nebraska - Lincoln. It has been accepted for inclusion in Papers in Natural Resources by an authorized administrator of DigitalCommons@University of Nebraska - Lincoln. 
Published in Journal of Field Ornithology 83:2 (2012), pp. 122-129; doi: 10.1111/j.1557-9263.2012.00362.x

Copyright () 2012 Cory J. Gregory, Stephen J. Dinsmore, Larkin A. Powell, and Joel G. Jorgensen.

Journal of Field Ornithology @ 2012 Association of Field Ornithologists;

published by Wiley-Blackwell. Used by permission.

Submitted May 4, 2011; accepted February 15, 2012

\title{
Estimating the Abundance of Long-billed Curlews in Nebraska
}

\author{
Cory J. Gregory, ${ }^{1}$ Stephen J. Dinsmore, ${ }^{1}$ Larkin A. Powell, ${ }^{2}$ and Joel G. Jorgensen ${ }^{3}$ \\ 1. Department of Natural Resource Ecology and Management, Iowa State University, \\ 339 Science Hall II, Ames, Iowa 50011, USA \\ 2. School of Natural Resources, University of Nebraska, 3310 Holdrege Street, \\ 419 Hardin Hall, Lincoln, Nebraska 68583, USA \\ 3. Nebraska Game and Parks Commission, 2200 N. 33rd Street, Lincoln, Nebraska 68503, USA \\ Corresponding author - S. J. Dinsmore, email cootjr@iastate.edu
}

\begin{abstract}
Long-billed Curlews (Numenius americanus) are shorebirds of high conservation concern in North America. Populations have declined in the last 150 yr primarily due to habitat loss and conversion. We conducted a 2-yr study to estimate the density and statewide abundance of breeding Long-billed Curlews in Nebraska during 2008 and 2009. Surveys were conducted during the prenesting period in April when Long-billed Curlews were likely to be detected. We used a simple random sample of roadside survey routes $(N=39)$, each consisting of 405 -min point-counts at $800-\mathrm{m}$ intervals. We modeled detection probability and found that wind speed negatively affected detectability, but found no evidence of either year effects or observer bias. We estimated there were 0.0038 Long-billed Curlews per hectare ( 0.38 Long-billed Curlews per $\mathrm{km}^{2}$ ) along survey routes and, by extrapolation, estimated there were 23,909 ( $\mathrm{SE}=1685 ; 95 \%$ CI: 20,810 - 27,471) Long-billed Curlews in Nebraska. Our population estimate suggests that $\sim 15$ to $22 \%$ of the United States population of Long-billed Curlews is found in Nebraska. Curlews were not evenly distributed within our survey area, with the highest densities in the central Sandhills, an area dominated by grass-stabilized sand dunes and shallow wetlands, and the lowest densities in predominantly agricultural areas. Because Long-billed Curlews in Nebraska face many potential threats resulting from land-use changes, monitoring of the breeding population should be continued. Our survey method was efficient and yielded interpretable results; other states or regions should consider adopting this approach for estimating curlew abundance.
\end{abstract}

Resumen. Estimando la abundancia de Numenius americanus en Nebraska

Numenius americanus son aves playeras de alto interés de conservación en América del Norte. Sus poblaciones han disminuido en los últimos 150 años, debido principalmente a la pérdida y conversión de hábitat. Realizamos un estudio de 2 años para estimar la densidad y abundancia de individuos de N. americanus en estado reproductivo en toda Nebraska durante el 2008 y 2009 . Los muestreos se realizaron durante el período previa a la anidación en abril, cuando los $N$. americanus son propensos a ser detectados. Utilizamos una muestra aleatoria simple de las transectas de muestreo a lo largo de las carreteras $(N=39)$, cada uno compuesto por 40 muestreos de 5-min, ubicados en intervalos de 800-m. Modelamos la probabilidad de detección y encontramos que la velocidad del viento afectó negativamente a la detectabilidad, pero no encontramos ninguna evidencia de efectos de año o de sesgo entre observadores. Estimamos que habían 0,0038 N. americanus por hectárea $\left(0,38\right.$ N. americanus por $\left.\mathrm{km}^{2}\right)$ a lo largo de las transectas de muestreo y, por extrapolación, estimamos que habían 23909 (EE = 1.685, IC 95\%: 20 810-27 471) N. americanus en Nebraska. Nuestra estimación de la población sugiere que 15 a 22\% de la población de N. americanus en los Estados Unidos está en Nebraska. Los N. americanus no estaban distribuidos uniformemente dentro de nuestro área de estudio, con las densidades más altas en la región de los Sandhills centrales, una zona dominada por dunas de arena estabilizadas por pastos, y humedales poco profundos. Las densidades más bajas estaban en áreas predominantemente agrícolas. Debido a que los N. americanus en Nebraska enfrentan muchas amenazas potenciales, producto de cambios en el uso del suelo, el monitoreo de la población reproductora debe continuar. Nuestro método de muestreo fue eficiente y produjo resultados interpretables; otros estados o regiones deberían considerar adoptar este tipo de metodología para estimar la abundancia de Numenius.

Keywords: abundance, detection probability, distance sampling, Numenius americanus, Program Distance, roadside survey

Long-billed Curlews (Numenius americanus) are listed as birds of conservation concern in five United States Fish and Wildlife regions (Fellows and Jones 2009), and are classified as highly imperiled by the United States Shorebird Conservation Plan (USSCP; Brown et al. 2001, Fellows et 
al. 2001). These curlews breed in dry short- and mixed-grass prairies throughout portions of the Great Plains and winter along the west coast of the United States and Mexico, throughout interior Mexico, and in low numbers along the Gulf and east coasts of the United States (Dugger and Dugger 2002). Historically, Long-billed Curlews bred in grasslands throughout the Great Plains east to Indiana, Michigan, and probably even Ohio (Bent 1929). However, the breeding range of Long-billed Curlews now extends only east to western Nebraska and western South Dakota. During the last $150 \mathrm{yr}$, the breeding range of Long-billed Curlews is believed to have contracted by $\sim 30 \%$ (Fellows and Jones 2009), primarily due to conversion of native grasslands to row-crop agriculture (Bent 1929, Yocum 1956).

Comprehensive surveys confirming the breeding range of Long-billed Curlews in Nebraska are lacking, but most sources indicate they were once statewide breeders and were probably more common in the western half of the state (Ducey 2000). However, since 1900, the breeding range of Longbilled Curlews has been limited primarily to the Sandhills and shortgrass prairies of north-central and northwest Nebraska (Ducey 2000).

Throughout their breeding range, Brown et al. (2001) estimated a population of 20,000 Long-billed Curlews, and Morrison et al. (2006) later estimated the continental population at between 55,000 and 123,500 individuals. Stanley and Skagen (2007) used a stratified random sample of survey routes in 16 western states to estimate the United States population at 164,515 (SE $=42,047)$ breeding birds in 2004 and 109,533 $(\mathrm{SE}=31,060)$ in 2005. The large difference and low precision of these estimates suggest some difficulty in surveying a terrestrial shorebird that occurs at low densities across a large geographic area.

Currently, no estimate of the size of the breeding population of curlews in Nebraska is available and, because Nebraska is thought to contain a sizeable portion of the United States population, a repeatable, well-designed breeding survey of curlews is needed. Our objectives were to delineate the current breeding range of Long-billed Curlews in $\mathrm{Ne}-$ braska, and estimate the density of the breeding population. We used distance sampling (Buckland et al. 2004) to estimate the density of Long-billed Curlews, and extrapolated this density to provide an estimate of the statewide breeding population.

\section{Methods}

Study area. We conducted surveys for Longbilled Curlews in Nebraska during April 2008 and 2009. We used a distribution estimate from Breeding Bird Survey (BBS) data (Sauer et al. 2005) to narrow our sampling area to parts of 22 counties, primarily in the panhandle and north-central Nebraska (Figure 1). The dominant ecoregion of the eastern survey area was the Sandhills, a mix of grass-stabilized sand dunes and shallow wetlands that stretch from Box Butte County east to Rock and Loup counties (Schneider et al. 2005). The Sandhills are considered one of the largest wetland ecosystems in the country $\left(\sim 50,000 \mathrm{~km}^{2}\right.$; U.S. Fish and Wildlife Service 2007), the largest dune system in the western hemisphere, and one of the largest grass-stabilized dune systems in the world (Schneider et al. 2005). Land use in the Sandhills is $80 \%$ rangeland, $10 \%$ wild hay, $5 \%$ row-crop agriculture, $2 \%$ forest, $1 \%$ water, and $2 \%$ other uses (Miller 1998). The dominant ecoregion in the western portions of the survey area was mixed and shortgrass prairie that stretches from Sioux and Dawes counties south to Banner and Morrill counties.

Survey methods. We established a series of roadside survey routes $(N=39)$, each route consisting of 40 stops with each stop $800 \mathrm{~m}$ from the previous stop (Jones et al. 2003). Roadside surveys are an efficient method for surveying large areas where there is little public land and field crews are small (Stanley and Skagen 2007). For each survey route, we randomly selected (a) one sample unit (township) within the specified Long-billed Curlew range in Nebraska, (b) the starting point of each route, and (c) the direction of the route and turns at every intersection. We searched for Longbilled Curlews using binoculars for $5 \mathrm{~min}$ at each stop and used only visual observations in our analyses because of the difficulty of assigning detection distances to birds that were only heard.

We recorded the number of Long-billed Curlews, the distance in meters $(<1 \mathrm{~km})$ to curlews (measured with a laser rangefinder), and the time of all sightings in 1-min intervals. If a Long-billed Curlew was flushed from a roadside, we treated it as a detection in the first minute. We also recorded wind speed $(\mathrm{km} / \mathrm{h})$, which is thought to influence bird detectability (Robbins 1981), at the start, middle, and end of each survey. Surveys were con- 


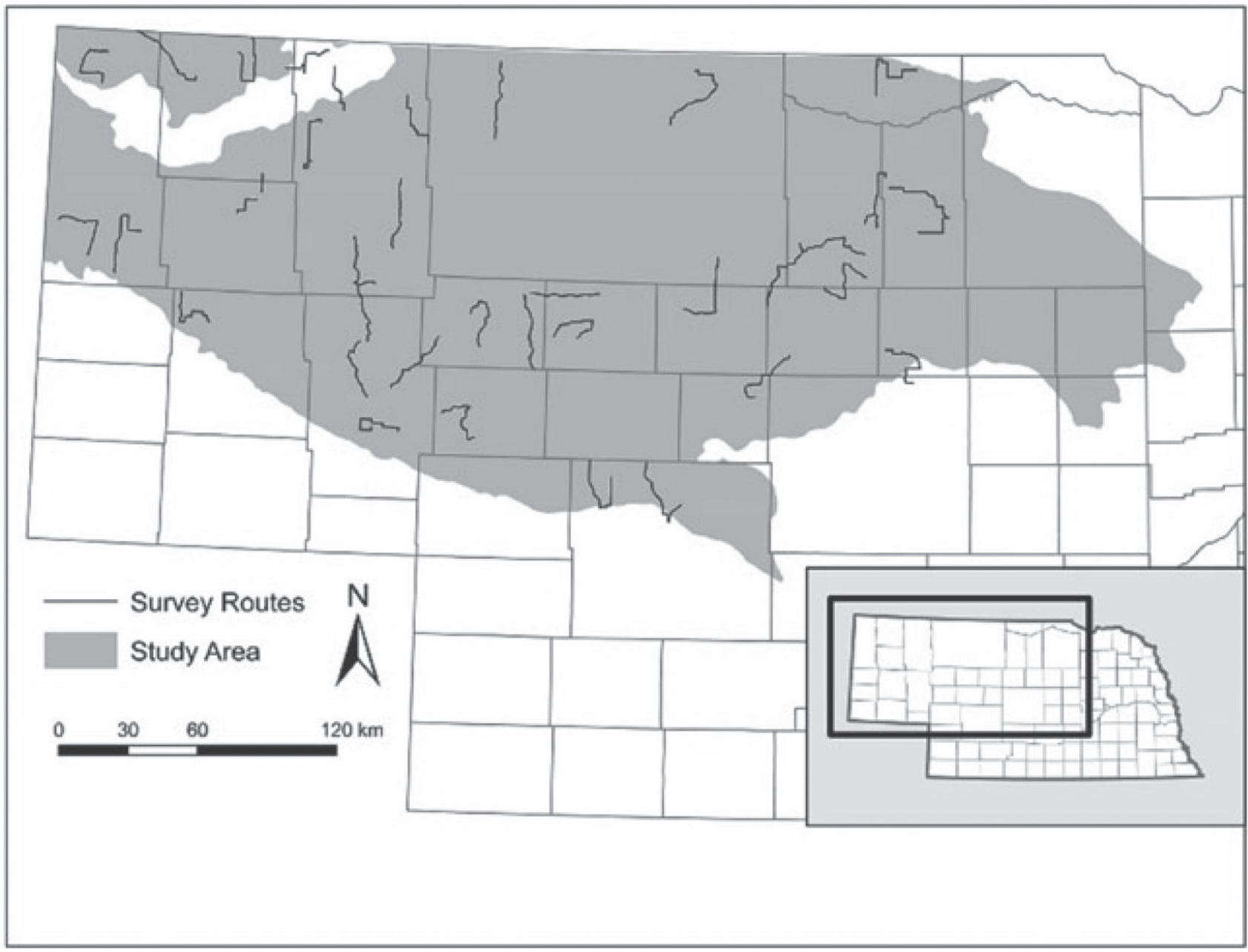

Figure 1. Long-billed Curlew (Numenius americanus) survey routes $(N=39)$ in Nebraska, 2008-2009. Route starting locations and directions were randomly chosen so some routes either overlapped between years $(N=3)$ or extended beyond the targeted survey area $(N=3)$.

ducted only during daylight hours (from $30 \mathrm{~min}$ before sunrise to 17:00) and during all weather conditions except heavy rain or snow, lightning, or wind speeds $>50 \mathrm{~km}$ per $\mathrm{h}$. If routes could not be completed due to inclement weather ( $N=6$ routes), we kept the completed points and used them in our analyses. We usually surveyed one route per day and never more than two. We did not characterize route-level habitat because most routes included a mix of the major habitat types found in the survey area. Moreover, 26 of 39 survey routes (67\%) were in the Sandhills where land cover is contiguous, relative to other portions of the curlew's range, and dominated by rangeland ( $80 \%$ of land area; Miller 1998) and thus had little site-to-site variation.

Surveys were conducted only on passable, public roads and streets; interstates, private roads, and urban areas were not surveyed. We sampled town- ships without replacement within a year, but sampled with replacement between years. Stratification of routes was considered in our survey design, but ultimately dismissed due to the lack of an existing defensible estimate of curlew density throughout the state, and the relatively homogeneous potential curlew habitat present throughout the sampling area that minimizes the need for habitat stratification. In addition, we used simple random sampling because stratification appeared to have no effect on the precision of population estimates in earlier surveys for Long-billed Curlews (Stanley and Skagen 2007, Jones et al. 2008).

Surveys were conducted during the preincubation period (April) to ensure that displaying curlews were easily detected (Redmond et al. 1981, Jones et al. 2003). We did not conduct surveys in May and June because of the secretive nature of in- 
cubating adults during that time (Stanley and Skagen 2007). We used roadside surveys instead of off-road or foot surveys because of the large area surveyed, the small number of surveyors, the limited survey period, and the limited access to private land that comprises most of western $\mathrm{Ne}$ braska. Although roadside bias was a concern, we believe effects were minimal in our study because (1) roadside habitats used by curlews are generally representative of their nonroadside habitat (Stanley and Skagen 2007), (2) there is no evidence that curlew behavior is affected by the presence of roads (Jones et al. 2008), (3) roads were often rural and lacked ditches, fencing, and other defining edges, and (4) there was little vehicular traffic and noise. Roads were present in all townships sampled, with no evidence of roads occurring systematically in wet areas that would positively bias population estimates.

An assumption of the removal method is that there is no movement of Long-billed Curlews during the survey period (Jones et al. 2008). If there is immigration or emigration during a survey, the resulting estimate can be biased. To limit survey bias, we did not include curlews only observed in flight, curlews that flew in and landed during the 5-min counts, or curlews that were only heard. We were also careful not to double-count curlews if any flew from previous points and landed in the vicinity of future points.

Analyses. We pooled 2008 and 2009 survey results for analyses in Program Distance (Thomas et al. 2009). We pooled data because preliminary analysis revealed no evidence of year effects in detectability (a model with year effects had a $\triangle$ AIC value of $>10$ when compared to a model with no year effects). Pooling was also acceptable because we surveyed breeding birds, and territorial curlews generally use the same area repeatedly between years (Clarke 2006). We divided the raw distance data into bins to minimize variation in distance estimates (Stanley and Skagen 2007). We explored the use of different distance bins and ultimately chose four bins ( 0 to $300 \mathrm{~m}, 301$ to $500 \mathrm{~m}, 501$ to $700 \mathrm{~m}$, and 701 to $1000 \mathrm{~m}$ ) because it resulted in adequate detections within each bin for our analyses. We imported the binned data and built four models to estimate overall density (Thomas et al. 2009). Model adjustments (Buckland et al. 2004) were uniform/simple polynomial, uniform/cosine, half-normal/cosine, half- normal/ hermite polynomial, hazard-rate/cosine, and hazard-rate/simple polynomial. In all analyses, hazard-rate adjustments failed to converge and were thereafter removed.

We created four models to test for potential differences in curlew detection rates. These models included the effects of observer, year, wind speed, and a model that did not consider any covariates. Both year and observer effects were analyzed by poststratifying the data and using Conventional Distance Sampling (CDS, Thomas et al. 2009). Because wind is thought to affect grassland bird activity patterns and thus their detections (Robbins 1981), we tested for wind effects by including wind speed $(\mathrm{km} / \mathrm{h})$ as a continuous covariate using the Multiple Covariate Distance Sampling (MCDS) analysis. Wind speeds were measured three times during each survey, but the intermediate wind speeds were later interpolated by smoothing values between known measurements. For routes with missing wind-speed data $(N=5)$, missing values were replaced by the overall mean wind speed. The result was an estimate of wind speed for each survey point. We used Akaike's Information Criterion (AIC) to select the best model(s) for inference. The model with the lowest AIC value was considered best and all models within 2.0 AIC units of that model were considered competitive. We measured model fit using the $x^{2}$ goodness-of-fit test and results with nonsignificant $P$-values were considered the best fitting model.

We used the estimate of density from the single best model to extrapolate to the sampling area defined as the shaded area in the curlew range map from the BBS (Sauer et al. 2005).We used ArcGIS 9.2 (Environmental Systems Research Institute, Inc., Redlands, CA) to calculate the sample area in hectares. We excluded urban areas from the sampling area by summing the digitized urban polygons around each town/city and subtracting this area total from the entire sampling area. Urban area data were provided within an ArcGIS layer and were already digitized. Lastly, we multiplied our overall density estimate from our best model to the total sampling area to obtain our final statewide population prediction $( \pm$ SE) along with a $95 \%$ confidence interval. We used the raw point count data in ArcMap to generate a map of relative curlew abundance for the state of Nebraska. Using the mean number of birds per route and restricting 


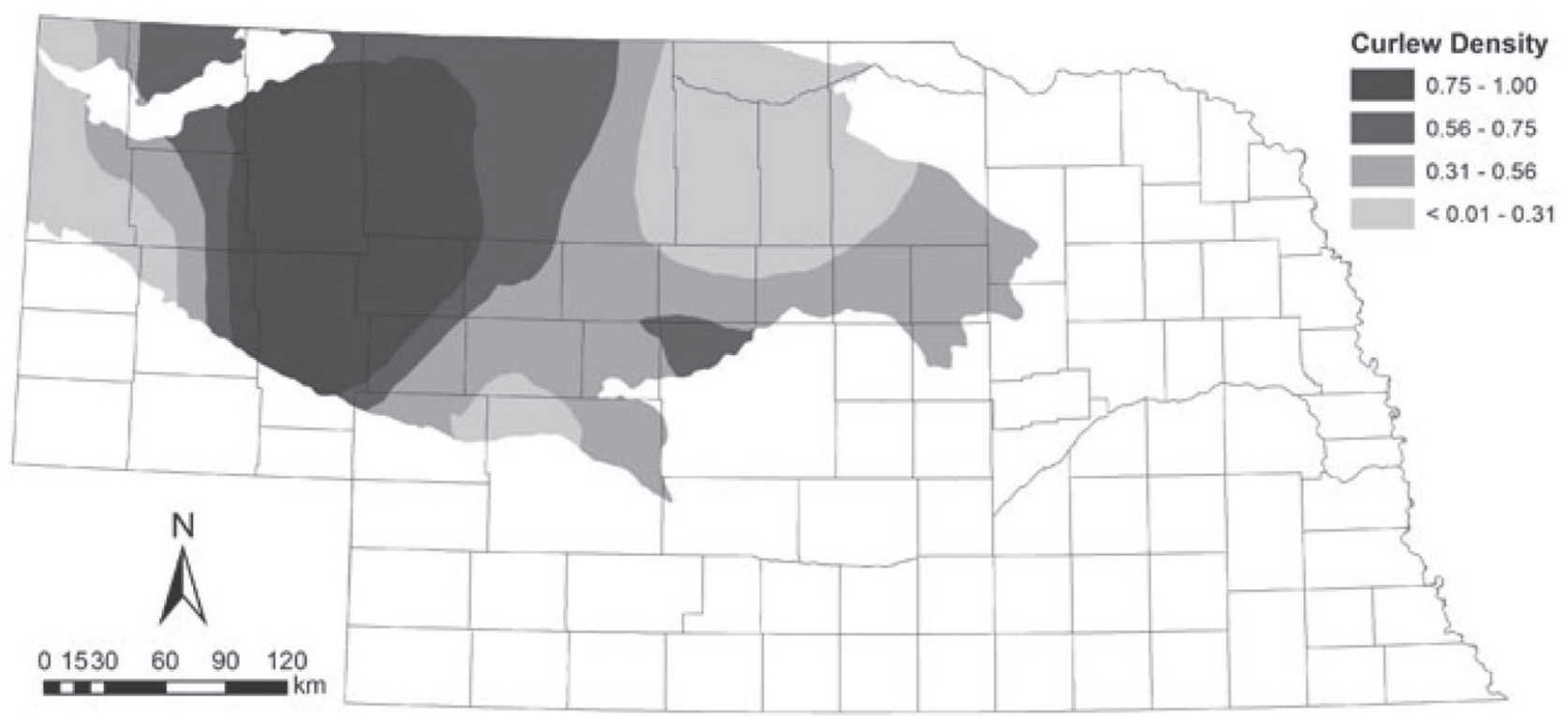

Figure 2. Relative abundance of Long-billed Curlews (Numenius americanus) in Nebraska, 2008-2009, estimated from interpolation kriging (ArcMap, ESRI; Geostatistical Analyst extension). The legend shows relative abundance (no units) and the original abundance was rescaled from zero (no individuals) to one (maximum abundance).

the area to the Sandhills ecoregion, we used kriging interpolation (Geostatistical Analyst extension) to generate the relative abundance map for curlews (Figure 2).

\section{Results}

During April 2008 and 2009, two observers surveyed 39 routes and 1398 points in western Nebraska (Figure 1). All routes were surveyed once from April 8 to 28, 2008, and from April 15 to 29, 2009. Routes took an average of $6.04 \mathrm{hrs}$ to complete in 2008 and $6.44 \mathrm{hrs}$ in 2009. Curlews were detected on 29 survey routes $(78 \%)$ and at 112 survey points $(8 \%)$, with 188 curlews visually detected (Table 1). Detections were mostly of single birds $(N$ $=140)$ or pairs $(N=43)$; detections of three or more birds were rare $(N=5)$.

The best model, which we used for all inferences, was the half-normal with a cosine adjustment (Table 2) plus wind speed (WIND) as a covariate and yielded a 7\% coefficient of variation (CV) on the estimate of density (Table 3). The density estimate was 0.0038 curlews per ha $(0.38$ curlews $/ \mathrm{km}^{2}$; Table 3$)$. We found no support for either observer (OBSERVER) or year (YEAR) effects in our analyses (all $\triangle$ AIC values $>2.0$; Table 3 ). We addressed the goodness-of- fit of the null model using the $x^{2}$ test and the data showed good fit ( $P$ $=1.00)$. We removed 11,849 ha of town/city areas from the total survey area of $6,298,351$ ha, resulting in a total survey area of $6,286,502$ ha. Based on our surveys, we estimated that 23,909 (SE = 1685; 95\% CI: 20,810-27,471 curlews) Long-billed Curlews were present in Nebraska. Breeding curlews were not evenly distributed within the survey area, with the highest densities in the central Sandhills (portions of Cherry, Garden, Grant, and Sheridan counties) and the lowest densities in the predominantly agricultural areas in the eastern portion of the survey area (Figure 2).

\section{Discussion}

Given the geographic range of Long-billed Curlews and the size of the breeding range in $\mathrm{Ne}$ braska, our statewide population estimate of 23,909 is consistent with expectations based on estimates by Stanley and Skagen (2007). Stanley and Skagen (2007) estimated that the total breeding population of Long-billed Curlews in the United States was 164,515 (SE = 42,047) in 2004 and 109,533 (SE = 31,060 ) in 2005 . If accurate, then $\sim 15$ to $22 \%$ of the U.S. breeding population of Long-billed Curlews occurs in Nebraska. However, we should not extrapolate our estimate to the curlew population in Canada; Stanley and Skagen (2007) did not include 
Table 1. Number of survey routes, Long-billed Curlews (Numenius americanus) detected, and Long-billed Curlews detected in each distance bin during roadside surveys in north and northwest Nebraska, 2008-2009.

\begin{tabular}{|c|c|c|c|c|c|c|c|}
\hline \multirow[b]{2}{*}{ Year } & \multirow{2}{*}{$\begin{array}{c}\text { Total number } \\
\text { of routes }\end{array}$} & \multirow{2}{*}{$\begin{array}{l}\text { Number of routes } \\
\text { with curlews }\end{array}$} & \multicolumn{3}{|c|}{ Distance bin $(\mathrm{m})$} & \multirow[b]{2}{*}{$>700-1000$} & \multirow{2}{*}{$\begin{array}{c}\text { Total number } \\
\text { of curlews }\end{array}$} \\
\hline & & & $0-300$ & $>300-500$ & $>500-700$ & & \\
\hline 2008 & 14 & 14 & 42 & 15 & 6 & 7 & 70 \\
\hline 2009 & 25 & 19 & 69 & 28 & 13 & 8 & 118 \\
\hline Total & 39 & 33 & 111 & 43 & 19 & 15 & 188 \\
\hline
\end{tabular}

Table 2. Model adjustments of binned Long-billed Curlew (Numenius americanus) density data in Nebraska, 20082009. Models are ordered by Akaike's Information Criterion (AIC). $K$ is the number of parameters and $\triangle \mathrm{AIC}$ is the AIC difference from the top model.

\begin{tabular}{lrrrrrr}
\hline Model $^{\mathrm{a}}$ & $K$ & \multicolumn{1}{c}{$\Delta \mathrm{AIC}^{\mathrm{b}}$} & Density birds per ha & D LCL $^{\mathrm{c}}$ & DUCL $^{\mathrm{d}}$ & $\mathrm{CV}^{\mathrm{e}}$ \\
\hline Half-normal + C & 2 & 0.00 & 0.005 & 0.004 & 0.006 & 0.088 \\
Half-normal + HP & 1 & 25.93 & 0.003 & 0.003 & 0.003 & 0.083 \\
Uniform + C & 2 & 32.90 & 0.002 & 0.002 & 0.003 & 0.080 \\
Uniform + SP & 3 & 48.60 & 0.003 & 0.002 & 0.003 & 0.146 \\
\hline
\end{tabular}

a. Models recommended by Buckland et al. (2004). Two hazard-rate models were removed due to poor convergence. $\mathrm{C}=$ cosine, $\mathrm{SP}=$ simple polynomial, and $\mathrm{HP}=$ hermite polynomial.

b. The AIC value of the top model was 410.80 .

c. Lower $95 \%$ confidence limit.

d. Upper $95 \%$ confidence limit.

e. Coefficient of variation.

Table 3. Models showing the effects of wind speed (WIND), observer (OBSERVER), and year (YEAR) on the detection probability of Long-billed Curlews (Numenius americanus) in Nebraska, 2008-2009. Models are ordered by Akaike's Information Criterion (AIC). $K$ is the number of parameters and $\triangle \mathrm{AIC}$ is the AIC difference from the top model. All models were run with a half-normal/cosine adjustment.

\begin{tabular}{lrrrrrr}
\hline Model & $K$ & $\Delta$ AIC $^{\mathrm{a}}$ & Density (birds per ha) & LCL $^{\mathrm{b}}$ & $\mathrm{UCL}^{\mathrm{c}}$ & $\mathrm{CV}^{\mathrm{d}}$ \\
\hline WIND & 3 & 0.00 & 0.0038 & 0.0033 & 0.0044 & 0.070 \\
EMPTY (NULL) & 2 & 2.17 & 0.0038 & 0.0032 & 0.0045 & 0.088 \\
OBSERVER & 4 & 4.37 & 0.0037 & 0.0031 & 0.0044 & 0.088 \\
YEAR & 4 & 5.36 & 0.0040 & 0.0034 & 0.0049 & 0.092 \\
\hline
\end{tabular}

a. The AIC value of the top model was 408.62 .

b. Lower $95 \%$ confidence limit.

c. Upper 95\% confidence limit.

d. Coefficient of variation.

that population in their study and little data exist for estimating the size of that population outside a single study in Alberta (Saunders 2001).

Another important finding was that wind can negatively affect detection rates of birds (Mack et al. 2002). We found that wind speed affected detection probability, a result consistent with the findings of other studies (Rosenstock et al. 2002, Bas et al. 2008). The best model in our study incorporated wind speed and we recommend that investigators also attempt to account for wind speed when modeling detection probability in future studies.
Fellows and Jones (2009) suggested that Nebraska could host a substantial portion of the overall breeding population of Long-billed Curlews. Our results support that conclusion and indicate that the Sandhills of Nebraska are an important breeding area for Long-billed Curlews. The Sandhills is a large region of contiguous dry grassland maintained primarily (as much as 95\%) as native grasslands for livestock production (Miller 1998, Schneider et al. 2005). This, along with the rough terrain, sandy soil, and semiarid conditions, prevents some of the land from being 
converted to agriculture (Schneider et al. 2005), creating suitable breeding habitat for Long-billed Curlews and supporting a substantial breeding population.

We found that curlew density varied across Nebraska (Figure 2), likely due to a combination of different dominant land cover types (e.g., grasslands, agriculture, forests, and urban areas) and differences in the habitat quality of grasslands occupied by curlews. The Sandhills of north-central and northwest Nebraska had the highest densities of curlews; land consisting of row-crop agriculture had lower densities. Although reasons for the varying densities of curlews within the Sandhills are not entirely clear, the mix of habitats may have been better for curlews in some regions. For example, local patterns of vegetation height, especially grass density and proximity to woody vegetation (Dugger and Dugger 2002), no doubt vary in the Sandhills and could have produced the observed density patterns.

Long-billed Curlews in Nebraska face many potential threats, many related to land-use patterns. The Sandhills are among the best-managed private rangelands in Nebraska, with typically lower-than-normal stocking rates of cattle, as producers guard against long-term damage to grasslands (Stubbendieck 1998, Kempema 2007). However, any future land-use changes could alter the Sandhills and reduce the importance of this landscape to curlew populations. One potential threat is the conversion of the remaining grasslands to row-crop agriculture (Kempema 2007), reducing the availability of suitable curlew habitat (Bent 1929, Yocum 1956). Another threat is the lack of regular fire regimes that historically helped maintain shorter and patchier vegetation used by curlews (Schneider et al. 2005). Land ownership may also play a role in curlew conservation in $\mathrm{Ne}-$ braska. Land in Nebraska is $98 \%$ privately owned, and the private lands in Nebraska may be critical for sustaining Long-billed Curlew populations in the United States (Schneider et al. 2005). Most curlews observed in our study $(>95 \%)$ were on private land, and we lacked adequate samples to compare curlew densities on private and public land. Another potential threat is wind energy development and encroachment on grasslands used by curlews (Fellows and Jones 2009). These potential threats highlight the need for Nebraska's segment of the curlew population to be included in conservation plans so that additional studies can better assess their potential impacts.

Our results indicate that the contiguous grasslands of the Sandhills of Nebraska support $\sim 15$ to $22 \%$ of the breeding population of Long-billed Curlews in the United States. This important segment of the U.S. population faces many potential threats resulting from land-use changes, emphasizing the need to continue monitoring efforts, better assess possible impacts of these threats, and continue to consider curlews in conservation plans.

Acknowledgments - We thank the staff at Crescent Lake National Wildlife Refuge for logistical support, the nearby private landowners (B. Bailey, J. Haskell, and E. Deitlein) for allowing access to their lands, and the Sandhills Task Force. Funding was provided by the Nebraska State Wildlife Grant Program and the Nebraska Wildlife Conservation Fund with additional assistance from the U.S. Fish and Wildlife Region 6 Nongame Migratory Bird Coordinator's office. LAP's contributions to this research were supported by Hatch Act funds through the University of Nebraska Agricultural Research Division, Lincoln, Nebraska. Field assistance was provided by T. Baerwald.

\section{Literature Cited}

Bas, Y., V. Devictor, J. Moussus, and F. Jiguet. 2008. Accounting for weather and time-of-day parameters when analyzing count data from monitoring programs. Biodiversity Conservation 17: 3403- 3416.

Bent, A. C. 1929. Life histories of North American shorebirds, Part 2. U.S. National Museum Bulletin 146, Washington, D.C.

Brown, S., C. Hickey, B. Harrington, and R. Gill. 2001. The U.S. Shorebird Conservation Plan, 2nd ed. Manomet Center for Conservation Sciences, Manomet, MA.

Buckland, S. T., D. R. Anderson, K. P. Burnham, J. L. Laake, D. L. Borchers, and L. Thomas. 2004. Introduction to distance sampling: Estimating abundance of biological populations. Oxford University Press, Oxford, UK.

Clarke, J. N. 2006. Reproductive ecology of Long-billed Curlews breeding in grazed landscapes of western South Dakota. M.S. thesis, South Dakota State University, Brookings, SD.

Ducey, J. E. 2000. Birds of the untamed west: The history of birdlife in Nebraska, 1750 to 1875. Making History, Omaha, NE.

Dugger, B. D., and K. M. Dugger. 2002. Long-billed Curlew (Numenius americanus). In: The Birds of North America, No. 628 (A. Poole \& F. Gill, eds.). The Birds of North America, Inc., Philadelphia, PA. 
Fellows, S. D., and S. L. Jones. 2009. Status assessment and conservation action plan for the Long-billed Curlew (Numenius americanus). U.S. Department of Interior, Fish and Wildlife Service, Biological Technical Publication, FWS/BTP-R6012- 2009, Washington, D.C.

Fellows, S., K. Stone, S. Jones, N. Damude, and S. Brown [online]. 2001. Central Plains/Playa Lakes regional shorebird conservation plan, version 1.0; $\underline{\mathrm{http}: / /}$ www.fws.gov/shorebirdplan/RegionalShorebird/ downloads/CPPLR.doc (accessed March 4, 2011).

Jones, S. L., C. S. Nations, S. D. Fellows, and L. L. McDonald. 2008. Breeding abundance and distribution of Long-billed Curlews (Numenius americanus) in North America. Waterbirds 31: 1-14.

— , T. R. Stanley, S. K. Skagen, and R. L. Redmond [online]. 2003. Long-billed Curlew (Numenius americanus) rangewide survey and monitoring guidelines. U.S. Department of Interior, Fish and Wildlife Service, Denver, CO; http://mountainprairie.fws. gov/species/birds/longbilledcurlew/long-billedcurlews\%20study\%20plan-photos\%2012-2003.pdf (accessed November 4, 2010)

Kempema, S. L. F. 2007. The influence of grazing systems on grassland bird density, productivity, and species richness on private rangeland in the Nebraska Sandhills. M.S. thesis, University of NebraskaLincoln, Lincoln, NE.

Mack, D. E., M. G. Raphael, and J. L. Laake. 2002. Probability of detecting Marbled Murrelets at sea: Effects of single versus paired observers. Journal of Wildlife Management 66: 865-873.

Miller, S. M. 1998. Land development and use. In: An Atlas of the Sand Hills (A. S. Bleed \& C. A. Flowerday, eds.), pp. 219-238. University of Nebraska-Lincoln, Lincoln, NE.

Morrison, R. I. G., B. J. McCaffery, R. E. Gill, S. K. Skagen, S. L. Jones, G. W. Page, C. L. Gratto-Trevor, and B. A. Andres. 2006. Population estimates of North American shorebirds. Water Study Group Bulletin 111: 67-85.

Redmond, R. L., T. K. Bicak, and D. A. Jenni. 1981. An evaluation of breeding season census techniques for Long-billed Curlews (Numenius americanus). Studies in Avian Biology 6: 197-201.
Robbins, C. S. 1981. Estimating numbers of terrestrial birds. Studies in Avian Biology 6: 301-310.

Rosenstock, S. S., D. R. Anderson, K. M. Giesen, T. Leukering, and M. F. Carter. 2002. Landbird Counting Techniques: Current Practices and An Alternative. Auk 119: 46-53.

Sauer, J. R., J. E. Hines, and J. Fallon. 2005. The North American Breeding Bird Survey, Results and Analysis, 1966-2004. Version 2005.2. U.S. Department of Interior, Geological Survey, Patuxent Wildlife Research Center, Laurel, MD.

Saunders, E. J. 2001. Population estimate and habitat associations of the Long-billed Curlew (Numenius americanus) in Alberta. Alberta Species at Risk Report No. 25, Edmonton, $\mathrm{AB}$, Canada.

Schneider, R., M. Humpert, K. Stoner, and G. Steinauer. 2005. The Nebraska Natural Legacy Project: A Comprehensive Wildlife Conservation Strategy. Nebraska Game and Parks Commission, Lincoln, NE.

Stanley, T. R., and S. K. Skagen. 2007. Estimating the breeding population of Long-billed Curlews in the United States. Journal of Wildlife Management 71: 2556-2564.

Stubbendieck, J. 1998. Range management. In: An Atlas of the Sand Hills (A. S. Bleed \& C. A. Flowerday, eds.), pp. 239-245. University of Nebraska-Lincoln, Lincoln, NE.

Thomas, L., J. L. Laake, E. Rexstad, S. Strindberg, F. F. C. Marques, S. T. Buckland, D. L. Borchers, D. R. Anderson, K. P. Burnham, M. L. Burt, S. L. Hedley, J. H. Pollard, J. R. B. Bishop, and T. A. Marques [online]. 2009. Distance 6.0 Release 2. Research Unit for Wildlife Population Assessment, University of St. Andrews, St. Andrews, UK; http://www.ruwpa.st-and. ac.uk/distance/ (accessed December 5, 2009).

U.S. Fish and Wildlife Service [online]. 2007. The Sandhills, building partnerships for an ecosystem; http:// www.fws.gov/mountain-prairie/pfw/ne/ne4.htm (accessed November 4, 2010)

Yocum, C. F. 1956. Re-establishment of breeding populations of Long-billed Curlews in Washington. Wilson Bulletin 68: 228-231. 